\title{
Productive Qualities of Beef Cattle Breeds in the conditions of the Southern Trans-Urals
}

\author{
Bakharev A. A. \\ FSBEI HE Northern Trans-Ural SAU \\ Tyumen, Russia \\ e-mail: salers@mail.ru \\ Fomintsev K.A. \\ FSBEI HE Northern Trans-Ural SAU \\ Tyumen, Russia \\ e-mail: salers@mail.ru
}

\author{
Sheveleva O. M. \\ FSBEI HE Northern Trans-Ural SAU \\ Tyumen, Russia \\ e-mail: olgasheveleva72@mail.ru \\ Grigoriev K. N. \\ FSBEI HE Northern Trans-Ural SAU \\ Tyumen, Russia \\ e-mail: salers@mail.ru
}

\author{
Bugasov B.Zh. \\ FSBEI HE Northern Trans-Ural SAU \\ Tyumen, Russia \\ e-mail: salers@mail.ru
}

\begin{abstract}
The paper deals with the topic of the development of the beef cattle breeding industry in the Tyumen region. The dynamics of the productive qualities of French beef breeds for a fifteen-year breeding period in the conditions of the south of the Tyumen region are analyzed. The object of the study is imported breeds such as Charolais, limousine, Salers and Aubrac. In the research process, the main economically useful and technological qualities were analyzed. Research results show that over a fifteenyear period of breeding French beef cattle in the Tyumen region, the annual increase in livestock ranges from 10 to $12 \%$, the age of heifer insemination decreases to 19 months, calves reach business output up to $87 \%$, milk production reaches up for calves up to 237 $\mathrm{kg}$ and heifers up to $218 \mathrm{~kg}$. Evaluation of a complex of productive qualities shows that more than $90 \%$ of animals fully comply with the requirements of the standard. The experience of breeding cattle of French beef breeds in the conditions of the Tyumen region shows that animals have fully adapted to the new living conditions and have formed an important strategic reserve in the formation of the specialized industry of cattle breeding in the Russian Federation. Herewith, local breeders of high-quality meat give greater preference to such breeds as Hereford, Aubrac and Salers, which amounts to 30.2, 31.9 and $20.7 \%$, and limousine and Charolais, which amounts to 12.0 and $5.2 \%$ respectively from the total population. This is explained by the complex of economic and biological features of these breeds, namely, modest requirements, precocity, reproductive abilities and other productive qualities.
\end{abstract}

Keywords- beef cattle breeding, history of the idustry development, Charolais, limousine, Salers and Aubrac beef breeds

\section{INTRODUCTION}

A cattle breeding is a leading branch of agriculture. At the present stage of development of agricultural production one of the important and complex problems facing the agro-industrial complex of the country is the increase in the production of meat and, above all, beef. This task can be fulfilled by creating an industry of specialized beef cattle. But given the prospects for the development of the industry of beef cattle in various regions of the country, including Siberia, the available array of breeding animals of meat breeds, both in terms of number and breed structure, is clearly insufficient. Therefore, it is necessary to develop beef cattle breeding through the use of domestic breeds, and to attract new promising resources of the global gene pool, among which are breeds of French root of origin. It is not by chance that in many countries of the world, FrenchItalian meat breeds are preferred, which are distinguished by their long growth and high growth intensity, and the desired ratio of nutrients in the carcase [1-3].

\section{PROBLEM OVERVIEW}

In the Tyumen region, the development of beef cattle breeding has had several stages. A number of farms were engaged in raising beef cattle in the 1960s - 1980s. In addition, there were 19 fattening enterprises in the region, united in the trust "Skotoprom". Several farms in the oblast were engaged in raising livestock of specialized meat breeds: Charolais, Shorthorn, Limousin, Hereford, and Kazakh white-headed. But by the end of the $80 \mathrm{~s}$, there was almost no beef cattle in the region.

The beginning of the second stage of the industry formation can be attributed to 1996, when Hereford breed cattle was purchased from the Omsk Region, and then in 2000 from the Novosibirsk and Chelyabinsk Regions. On the basis of this cattle, 2 breeding specialists of the Hereford breed were created $[4,5]$.

The third stage dates back to 2002, when OJSC Tyumen Meat Company imported 4 types of French cattle into the southern regions of the Tyumen Region: Charolais, Limousin, Salers and Aubrac. Among them, Charolais breeds include 325 
animal units, or $23 \%$ of the total imported livestock, Limousin - 397 head (28\%), Salers - 278 head (20) and 425 head, or 29\%. In the second batch in 2007, the herd was replenished with 800 heifers and 12 calves (Table 1) [6].

At the beginning of 2017, the total number of livestock of specialized French beef cattle was 7,000 head, including 3,100 breeding stock.

The fourth stage (presumably in the present time): 1) breeding, 2) industrial and absorption of meat breeds in lowproducing dairy herds (farms).
TABLE I. THE NUMBER OF IMPORTATION OF FRENCH BEEF CATTLE

\begin{tabular}{|l|c|c|c|}
\hline \multicolumn{1}{|c|}{ Breed } & calves & heifers & $\begin{array}{c}\text { Availability in \% } \\
\text { for the importation } \\
\text { on 01.01.2017 }\end{array}$ \\
\hline Charolais & 16 & 313 & 0 \\
\hline Limousin & 18 & 483 & 10 \\
\hline Salers & 12 & 446 & 11 \\
\hline Aubrac & 17 & 932 & 15 \\
\hline Total & 63 & 2174 & - \\
\hline
\end{tabular}

The dynamics of the number of breeding stock of French breeds are presented in Fig. 1.

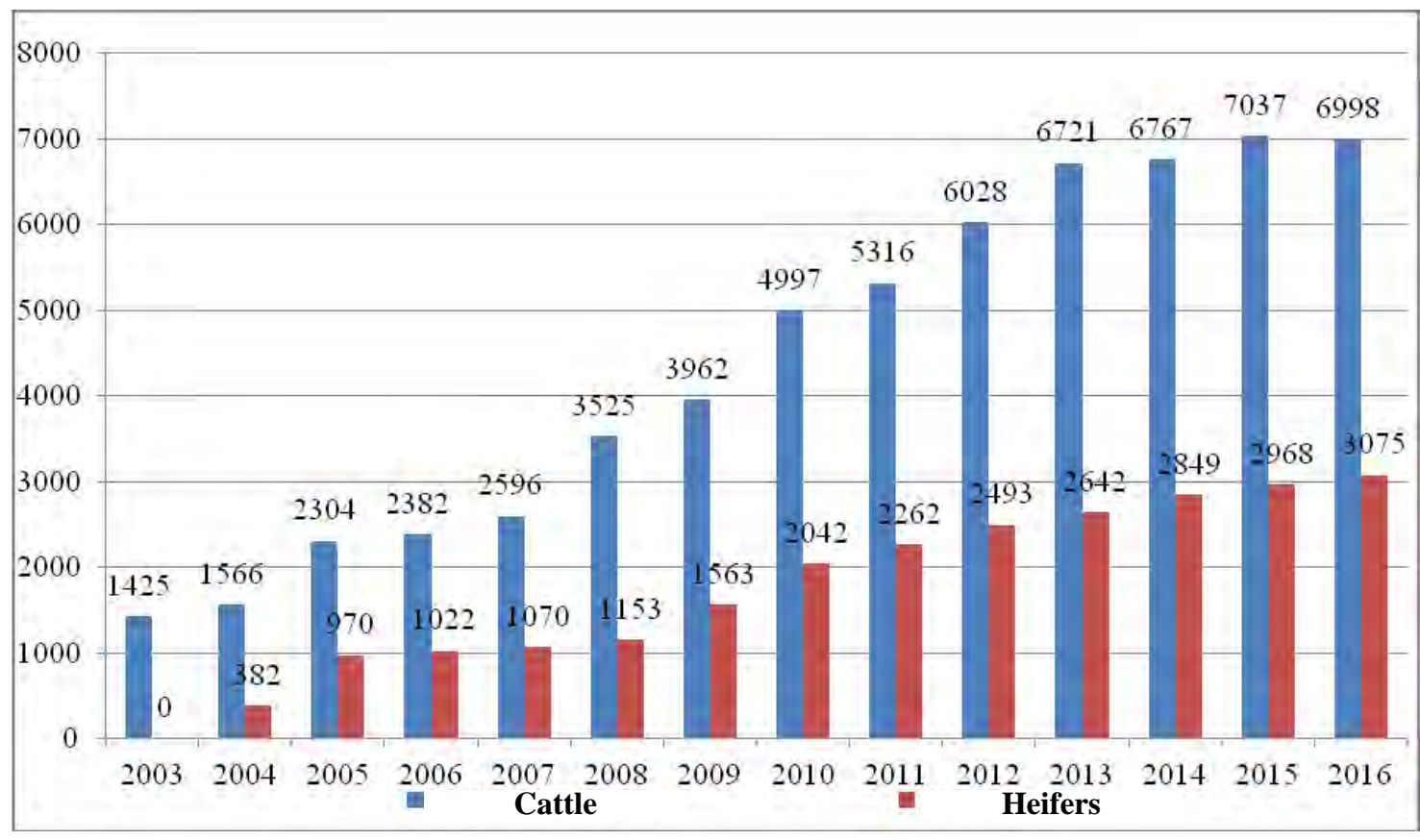

Fig. 1. - The dynamics of the number of purebred beef cattle in JSC "Tyumen meat company"

In the dynamics of years, a gradual increase in the number of herds of animals is traced, but in 2008 there was a sharp increase due to the importation of a new batch of livestock. At the beginning of 2017, the total number of livestock of specialized French beef cattle was 7,000 head, including 3,100 breeding stock.

In the rock ratio, the structure of the livestock of beef cattle of the Tyumen region was as follows (Table 2): the total population of animals of Charolais breed is $5.2 \%$ of the total number of animals of all breeds, animals of Limousin breed $12.0 \%$, Salers $-20.7 \%$, Hereford $-30.2 \%$, and Aubrac $-31.9 \%$. This ratio is primarily due to the preference in breeding certain breeds and reflects the best adaptation of cattle breed Aubrac and Salers.

From the moment of delivery of all breeds to animals in the new breeding conditions, there is a continuous change in the main production indicators, while it should be noted that this dynamics tends to increase when the recommended parameters meet the breeding and productive qualities of animals [7, 8].

The work is executed with support of grant of President RF MD2403.2018.11
TABLE II. THE NUMBER OF PUREBRED BEEF CATTLE IN THE TYUMEN REGION ON 01/01/2017

\begin{tabular}{|l|c|c|}
\hline \multirow{2}{*}{ Breed } & \multicolumn{2}{|c|}{ Number } \\
\cline { 2 - 3 } & Head & $\%$ \\
\hline Charolais & 430 & 5.2 \\
\hline Limousin & 993 & 12.0 \\
\hline Salers & 1720 & 20,7 \\
\hline Aubrac & 2648 & 31.9 \\
\hline Hereford & 2512 & 30.2 \\
\hline Total & 8303 & 100 \\
\hline
\end{tabular}

The process of acclimatization of animals is one of the most time-consuming and complex biological processes, during which the individuals caught in the new environmental conditions undergo significant changes in biological traits that are hereditarily fixed and transmitted to the offspring $[9,10]$.

The purpose of our research was to study in a comparative aspect the pedigree qualities and the economic and biological features of the growth and development of young meat 
imported in the process of their acclimatization from birth to eighteen months of age.

The material for the research was the first offspring (the first genetic-ecological generation) obtained in our zone from the cattle of French meat breeds [11].

To carry out scientific and business experience from the early-spring calf first-haul calf, 5 groups of young stock (calves and heifers) with 12 head each were selected and formed: the Hereford, Charolais, Limousine, Salers and The samples were taken as experimental groups (group II, III, IV, V). Selection of animals in groups was carried out taking into account the origin, age, development and state of health.

Experimental animals were raised on the technology of beef cattle. Before entering the pasture, the young were kept loose in light-type premises, having free access to the walking area, and from May to October together with their mothers were on the pasture. Weaning was performed at 8 months of age. After weaning, the animals of the studied groups were put on growing. Feeding during this period was carried out according to the norms, taking into account live weight and age of animals. The level of feeding and conditions in the studied groups were of the same type.

The living mass was taken into account by individually weighing the experimental calves monthly, and later in certain age periods. Based on the weighing results, the average daily increment was calculated.

Taking into account the feed intake of the bulls was carried out by weighing the number of specified feed and not eaten residues, and the amount consumed by calves milk - by weighing them before and after sucking cows-mothers.

The digestibility of the basic nutrients of the rations in the organism of animals was determined by the method of inert indicators, for which three head of bulls of each breed were taken at the age of 15 months $[12,13]$.

\section{RESULTS OF RESEARCH}

Live weight as one of the most important economically useful features that characterize growth, and the meat quality of animals is presented in Table 1.

With other conditions of cultivation being equal, animals of different breeds reacted differently to new environmental conditions. The largest born bullheads were of the Charolais breed; at birth they had the large-size characteristic as common for the breed, and according to the studied indicator they exceeded their peers of the Limousine breed by $4.8 \mathrm{~kg}$ ( $\mathrm{P}>$ 0.95), Aubrac - 8.1 ( $\mathrm{P}>0.99)$, Salers - 9.5, and Hereford - by $10.6 \mathrm{~kg}(\mathrm{P}>0.999)$. In young Charolais, the weight advantage at birth has been preserved in further age periods: when weaned, the young Charolais breed exceeded their analogs of the limousine and Salers in the same degree by $18 \mathrm{~kg}$, the breed was 14.6 Hereford by $10.4 \mathrm{~kg}$.
TABLE III. DyNAmics OF BODY WEIGHT OF YOUNG ANimals ( $\bar{X} \pm S \bar{x}$ ) , KG $(\mathrm{N}=12)$

\begin{tabular}{|c|c|c|c|c|c|}
\hline \multirow{3}{*}{$\begin{array}{l}\text { Age, } \\
\text { months }\end{array}$} & \multicolumn{5}{|c|}{ Breed } \\
\hline & Hereford & Charolais & Limousin & Salers & $\begin{array}{c}\text { Aubra } \\
\text { c }\end{array}$ \\
\hline & \multicolumn{5}{|c|}{ Bull } \\
\hline $\begin{array}{c}\text { При } \\
\text { рождении }\end{array}$ & $\begin{array}{c}25,8 \pm \\
0,65 \\
\end{array}$ & $\begin{array}{l}36,4 \pm \\
2,09^{* * *}\end{array}$ & $\begin{array}{l}31,6 \pm \\
0,51^{* * *} \\
\end{array}$ & $\begin{array}{c}26,9 \pm \\
0,39 \\
\end{array}$ & $\begin{array}{c}28,3 \pm \\
1,04 \\
\end{array}$ \\
\hline 6 & $\begin{array}{c}164,5 \pm \\
1,24\end{array}$ & $\begin{array}{c}179,2 \pm \\
6,53^{*}\end{array}$ & $\begin{array}{c}170,3 \pm \\
3,90\end{array}$ & $\begin{array}{c}161,8 \pm \\
3,56\end{array}$ & $\begin{array}{c}162,1 \\
\pm 3,58 \\
\end{array}$ \\
\hline 8 & $\begin{array}{c}200,6 \pm \\
8,64 \\
\end{array}$ & $\begin{array}{c}211,0 \pm \\
6,13 \\
\end{array}$ & $\begin{array}{c}192,9 \pm \\
5,23\end{array}$ & $\begin{array}{c}193,4 \pm \\
5,22 \\
\end{array}$ & $\begin{array}{r}196,4 \\
\pm 5,60 \\
\end{array}$ \\
\hline 12 & $\begin{array}{c}286,3 \pm \\
5,62\end{array}$ & $\begin{array}{c}317,5 \pm \\
10,92^{*}\end{array}$ & $\begin{array}{c}287,8 \pm \\
10,67 \\
\end{array}$ & $\begin{array}{c}295,3 \pm \\
8,12 \\
\end{array}$ & $\begin{array}{r}297,5 \\
\pm 9,10 \\
\end{array}$ \\
\hline 15 & $\begin{array}{c}349,5 \pm \\
10,17\end{array}$ & $\begin{array}{c}396,4 \pm \\
8,75^{* *}\end{array}$ & $\begin{array}{c}356,5 \pm \\
9,15\end{array}$ & $\begin{array}{c}364,7 \pm \\
7,94\end{array}$ & $\begin{array}{r}368,0 \\
\pm 7,47 \\
\end{array}$ \\
\hline \multirow[t]{2}{*}{18} & $\begin{array}{c}432,2 \pm \\
15,43\end{array}$ & $\begin{array}{c}487,5 \pm \\
13,53^{*}\end{array}$ & $\begin{array}{c}437,9 \pm \\
21,43\end{array}$ & $\begin{array}{c}451,6 \pm \\
18,28\end{array}$ & $\begin{array}{c}457,5 \\
\pm \\
18,34\end{array}$ \\
\hline & \multicolumn{5}{|c|}{ Heifers } \\
\hline At birth & $\begin{array}{c}24,3 \pm \\
0,97 \\
\end{array}$ & $\begin{array}{l}34,5 \pm \\
2,05^{* * * *}\end{array}$ & $\begin{array}{l}30,3 \pm \\
0,81^{* * *}\end{array}$ & $\begin{array}{c}26,2 \pm \\
0,42^{*} \\
\end{array}$ & $\begin{array}{c}27,6 \pm \\
0,79^{*} \\
\end{array}$ \\
\hline 6 & $\begin{array}{c}158,4 \pm \\
2,16 \\
\end{array}$ & $\begin{array}{c}170,1 \pm \\
4,27^{*} \\
\end{array}$ & $\begin{array}{c}163,6 \pm \\
6,47 \\
\end{array}$ & $\begin{array}{c}157,9 \pm \\
3,67 \\
\end{array}$ & $\begin{array}{r}156,5 \\
\pm 3,50 \\
\end{array}$ \\
\hline 8 & $\begin{array}{c}190,3 \pm \\
4,33\end{array}$ & $\begin{array}{c}203,3 \pm \\
6,76 \\
\end{array}$ & $\begin{array}{c}185,5 \pm \\
4,50 \\
\end{array}$ & $\begin{array}{c}182,3 \pm \\
4,84 \\
\end{array}$ & $\begin{array}{r}184,5 \\
\pm 6,20 \\
\end{array}$ \\
\hline 12 & $\begin{array}{c}265,6 \pm \\
7,54 \\
\end{array}$ & $\begin{array}{c}291,6 \pm \\
15,80 \\
\end{array}$ & $\begin{array}{c}268,7 \pm \\
12,29 \\
\end{array}$ & $\begin{array}{c}264,6 \pm \\
9,08 \\
\end{array}$ & $\begin{array}{r}267,3 \\
\pm 7,68 \\
\end{array}$ \\
\hline 15 & $\begin{array}{c}304,3 \pm \\
7,93 \\
\end{array}$ & $\begin{array}{c}338,2 \pm \\
10,56^{*} \\
\end{array}$ & $\begin{array}{c}314,2 \pm \\
7,36 \\
\end{array}$ & $\begin{array}{c}311,9 \pm \\
4,87 \\
\end{array}$ & $\begin{array}{r}315,4 \\
\pm 9,27 \\
\end{array}$ \\
\hline 18 & $\begin{array}{c}362,0 \pm \\
12,24\end{array}$ & $\begin{array}{c}395,8 \pm \\
19,64\end{array}$ & $\begin{array}{c}369,8 \pm \\
17,59\end{array}$ & $\begin{array}{c}369,3 \pm \\
20,69\end{array}$ & $\begin{array}{c}371,4 \\
\pm \\
20,75\end{array}$ \\
\hline
\end{tabular}

Note: hereinafter, where * $\mathrm{P}>0.95 ; * * \mathrm{P}>0.99 ; * * * \mathrm{P}>0.999$ in comparison to the Hereford

At 15 months of age, the bulls of the breed Hereford and limousine were still inferior to the Charolais breed in terms of body weight between 46.9 and $39.9 \mathrm{~kg}$ ( $\mathrm{P}>0.99)$; and animal breeds, Salers and Aubrac in the range of 31.7 and $28.4 \mathrm{~kg}(\mathrm{P}>$ $0.95)$.

At the end of the growing period, the charolais breed bulls had the highest live weight of $487.5 \mathrm{~kg}$, the Hereford and limousine animals had a lower weight -432.2 and $437.9 \mathrm{~kg}$. Calves of the Salers and Aubrac breeds in this indicator were 36 and $30 \mathrm{~kg}$ inferior to the Charolais calves.

In general, during all periods of cultivation, the animals of the Charolais breed were characterized by the highest live weight, the calves of this breed were more heavy and exceeded the rest of the studied groups in live weight. The low growth dynamics of the young breed of limousine is explained by the poor adaptability of this breed to new environmental conditions.

Similar patterns in the change in body weight over the growing periods were also established for the live weight of the heifers of the studied rocks.

The data of average daily gains by periods of growing animals of different groups also testifies to the unequal growth rate of the young (Table 4). 
TABLE IV. AVERAGe DaILY GROWth OF YOUNG Stock $(\bar{X} \pm S \bar{x}), \mathrm{G}$ $(\mathrm{N}=12)$

\begin{tabular}{|c|c|c|c|c|c|}
\hline \multirow{2}{*}{$\begin{array}{c}\text { Age } \\
\text { period, } \\
\text { months }\end{array}$} & \multicolumn{5}{|c|}{ Breed } \\
\hline & Hereford & Charolais & Limousin & Salers & Aubrac \\
\hline & \multicolumn{5}{|c|}{ Calves } \\
\hline $0-6$ & $\begin{array}{c}770.5 \pm \\
21.35 \\
\end{array}$ & $\begin{array}{c}793.3 \pm \\
27.31 \\
\end{array}$ & $\begin{array}{c}770.0 \pm \\
15.82 \\
\end{array}$ & $\begin{array}{c}749.4 \pm \\
13.93 \\
\end{array}$ & $\begin{array}{c}743.3 \pm \\
26.63\end{array}$ \\
\hline $0-8$ & $\begin{array}{c}728.3 \pm \\
25.94\end{array}$ & $\begin{array}{c}727.5 \pm \\
19.50\end{array}$ & $\begin{array}{c}672.1 \pm \\
21.58\end{array}$ & $\begin{array}{c}693.7 \pm \\
18.58\end{array}$ & $\begin{array}{c}700.4 \pm \\
15.95\end{array}$ \\
\hline $8-12$ & $\begin{array}{c}714.1 \pm \\
37.51 \\
\end{array}$ & $\begin{array}{l}887.5 \pm \\
35.15^{* *}\end{array}$ & $\begin{array}{c}790.8 \pm \\
29.63 \\
\end{array}$ & $\begin{array}{l}849.2 \pm \\
31.26^{*}\end{array}$ & $\begin{array}{c}842.5 \pm \\
45.20^{*}\end{array}$ \\
\hline $12-15$ & $\begin{array}{c}702.2 \pm \\
39.53 \\
\end{array}$ & $\begin{array}{l}876.6 \pm \\
32.42^{* *}\end{array}$ & $\begin{array}{c}763.3 \pm \\
36.17\end{array}$ & $\begin{array}{c}771.1 \pm \\
36.50\end{array}$ & $\begin{array}{c}783.3 \pm \\
37.14\end{array}$ \\
\hline $15-18$ & $\begin{array}{c}918.8 \pm \\
35.64\end{array}$ & $\begin{array}{c}1012.2 \pm \\
54.28\end{array}$ & $\begin{array}{c}904.4 \pm \\
45.43\end{array}$ & $\begin{array}{c}965.6 \pm \\
36.73\end{array}$ & $\begin{array}{c}994.4 \pm \\
28.30\end{array}$ \\
\hline \multirow[t]{2}{*}{$0-18$} & $\begin{array}{c}752.5 \pm \\
25.34\end{array}$ & $\begin{array}{c}835.3 \pm \\
28.06^{*}\end{array}$ & $\begin{array}{c}752.4 \pm \\
27.71\end{array}$ & $\begin{array}{c}786.5 \pm \\
29.14\end{array}$ & $\begin{array}{c}794.8 \pm \\
15.24\end{array}$ \\
\hline & \multicolumn{5}{|c|}{ Heifers } \\
\hline $0-6$ & $\begin{array}{l}745.0 \pm \\
35.76 \\
\end{array}$ & $\begin{array}{c}753.3 \pm \\
25.79 \\
\end{array}$ & $\begin{array}{c}740.6 \pm \\
17.24 \\
\end{array}$ & $\begin{array}{c}731.7 \pm \\
14.40\end{array}$ & $\begin{array}{c}716.1 \pm \\
39.47 \\
\end{array}$ \\
\hline $0-8$ & $\begin{array}{c}691.6 \pm \\
12.47\end{array}$ & $\begin{array}{c}703.3 \pm \\
11.62\end{array}$ & $\begin{array}{c}646.7 \pm \\
19.81\end{array}$ & $\begin{array}{c}650.4 \pm \\
17.36\end{array}$ & $\begin{array}{c}653.7 \pm \\
23.08\end{array}$ \\
\hline $8-12$ & $\begin{array}{c}627.5 \pm \\
49.60\end{array}$ & $\begin{array}{c}735.8 \pm \\
51.40\end{array}$ & $\begin{array}{c}693.3 \pm \\
30.27\end{array}$ & $\begin{array}{c}685.8 \pm \\
28.11\end{array}$ & $\begin{array}{c}690.0 \pm \\
31.84\end{array}$ \\
\hline $12-15$ & $\begin{array}{c}430.0 \pm \\
46.10\end{array}$ & $\begin{array}{c}517.7 \pm \\
34.53\end{array}$ & $\begin{array}{c}505.5 \pm \\
34.65\end{array}$ & $\begin{array}{c}525.5 \pm \\
37.94\end{array}$ & $\begin{array}{c}534.4 \pm \\
29.41\end{array}$ \\
\hline $15-18$ & $\begin{array}{c}641.1 \pm \\
34.58\end{array}$ & $\begin{array}{c}640.0 \pm \\
42.86\end{array}$ & $\begin{array}{c}617.8 \pm \\
47.52\end{array}$ & $\begin{array}{c}637.8 \pm \\
40.61\end{array}$ & $\begin{array}{c}622.2 \pm \\
44.26\end{array}$ \\
\hline $0-18$ & $\begin{array}{c}625.3 \pm \\
17.42\end{array}$ & $\begin{array}{c}669.0 \pm \\
26.18\end{array}$ & $\begin{array}{c}628.7 \pm \\
22.46\end{array}$ & $\begin{array}{c}635.3 \pm \\
25.39\end{array}$ & $\begin{array}{c}636.6 \pm \\
20.28\end{array}$ \\
\hline
\end{tabular}

Thus, in the milk period up to 6 months of age, all experimental animals showed fairly high average daily gains. At the end of the lactation period (by the age of 8 months), there was a decrease in the growth rate of the young, which is associated with a decrease in milk production.

The maximum average daily growth of bulls of all groups was from 15 to 18 months, it amounted to $1012.2 \mathrm{~g}$ in the bulls of the Charolais breed, the young growth of the breed had an insignificant lagging behind them by $18 \mathrm{~g}$, and the Salers calves were $46 \mathrm{~g}$ behind in this period $93 \mathrm{~g}$ Herefords and Limousines $-108 \mathrm{~g}$

In total, during the growing period, the average daily gain in animals of the Charolais breed was the largest and exceeded the young breed of Limousine and Hereford breed by $83 \mathrm{~g}$ (P> 0.95 ), and the calves of the breed Aubrac and Salers by 40.5 $48.8 \mathrm{~g}$

Differences in the growth rate of the heifers were not observed.

The study of the linear growth of experimental animals showed that the nature of changes in the articles and the proportions of the physique corresponded to the change in live weight. In terms of body indexes, French breed animals were characterized by wide body and high foot, they had well-made breasts, better developed hams, all this gives us reason to believe that the young of the studied breeds born in new environmental conditions showed good acclimatization abilities and retained its inherent type physique.

Our studies also included a study of the amount of feed consumed (Table 5).
TABLE V. CONSUMPTION OF FEED FOR THE PERIOD OF EXPERIENCE ON 1 HEAD, KG $($ CALVES N $=3)$

\begin{tabular}{|l|c|c|c|c|c|}
\hline \multirow{2}{*}{ Feed } & \multicolumn{5}{|c|}{ Breed } \\
\cline { 2 - 6 } & Hereford & $\begin{array}{c}\text { Charolai } \\
s\end{array}$ & Limousin & Salers & Aubrac \\
\hline Milk & 1195.0 & 1065.2 & 1083 & 1146 & 1172.0 \\
\hline Hey & 940.5 & 875.2 & 917.8 & 954.6 & 962.7 \\
\hline Straw & 141.6 & 116.0 & 126.3 & 141.1 & 136.2 \\
\hline Heylage & 1406.6 & 1829.5 & 1503.5 & 1450.2 & 1451.3 \\
\hline Greenness & 2330.7 & 2453.4 & 2517 & 2364 & 2354.0 \\
\hline Concentrate & 764.0 & 832.7 & 742.4 & 742.4 & 764.3 \\
\hline $\begin{array}{l}\text { EFU (Energy } \\
\text { feed unit) }\end{array}$ & 2776.2 & 2925.9 & 2778.2 & 2772.8 & 2801.7 \\
\hline $\begin{array}{l}\text { Digestible } \\
\text { Protein }\end{array}$ & 199.6 & 209.0 & 203.8 & 198.1 & 200.8 \\
\hline
\end{tabular}

Comparing the cost of feed, it can be seen that the young growth was raised medium-intensively. Experimental animals consumed slightly more feed compared to the young of the control group. The smaller amount of feed consumed by animals of the breed, Hereford, is due to their better digestibility. The greatest amount of feed was consumed by animals from the Charolais breed.

In the structure of the diet of bulls for the entire period of growing milk was (by nutritional value) $9.8-11.6 \%$, coarse $21.0-24.5 \%$, juicy $-17.2-21.6$, greenness $-19.7-21.3$ and concentrates $-26.5-28.1 \%$.

A significant difference in live weight, average daily weight gain, the development of individual articles in animals of different breeds, apparently, is caused not only by biological features, but also by the ability to uniquely absorb nutrients of the diet, their different digestibility $[14,15]$.

In this regard, we conducted a physiological experiment on the digestibility of nutrients (Table 6).

TABLE VI. NUTRIENT DIGESTIBILITY RATIOS FOR CALVES AT THE AGE OF 15 MONTHS $(\bar{X} \pm S \bar{x}), \%(\mathrm{~N}=3)$

\begin{tabular}{|l|c|c|c|c|c|}
\hline \multirow{2}{*}{ Rate } & \multicolumn{5}{|c|}{ Breed } \\
\cline { 2 - 6 } & \multirow{2}{*}{ Hereford } & $\begin{array}{c}\text { Charolai } \\
\text { S }\end{array}$ & Limousin & Salers & \multirow{2}{*}{ Aubrac } \\
\hline Dry & $70.8 \pm$ & $72.4 \pm$ & $70.5 \pm$ & $69.4 \pm$ & $70.9 \pm$ \\
substance & 0.86 & 0.78 & 0.72 & 0.68 & 0.37 \\
\hline Organic & $73.7 \pm$ & $73.8 \pm$ & $72.8 \pm$ & $72.4 \pm$ & $72.5 \pm$ \\
substance & 0.62 & 1.64 & 1.57 & 1.33 & 1.57 \\
\hline Raw protein & $66.8 \pm$ & $64.7 \pm$ & $63.9 \pm$ & $61.8 \pm$ & $61.5 \pm$ \\
& 1.64 & 2.47 & 1.83 & 1.08 & $0.37^{*}$ \\
\hline \multirow{2}{*}{ Raw gluten } & $65.5 \pm$ & $66.7 \pm$ & $63.3 \pm$ & $64.7 \pm$ & $68.6 \pm$ \\
& 1.27 & 1.41 & 2.15 & 0.72 & 0.42 \\
\hline Raw fat & $71.7 \pm$ & $74.6 \pm$ & $74.2 \pm$ & $71.5 \pm$ & $71.5 \pm$ \\
& 1.16 & 0.78 & 0.70 & 1.46 & 0.97 \\
\hline NES & & & & & \\
Nitrogen- & $77.9 \pm$ & $79.6 \pm$ & $79.4 \pm$ & $77.6 \pm$ & $78.3 \pm$ \\
free & 0.73 & 1.13 & 1.49 & 0.81 & 0.48 \\
extractive & & & & & \\
substances) & & & & \\
\hline
\end{tabular}

According to the results of the experiment, it was found that the nutrient digestibility ratios of the rations were quite high. Organic matter rations animals of all groups are digested the same. The rations in the experiment were balanced in protein 
content, but its absorption proceeded in a peculiar way. In the calves of the Charolais and limousine breeds, the protein digestibility coefficient was $64.3 \%$, the Salers and Aubrac breeds - $61.7 \%$. But the most intensively the protein was assimilated by the Herefords $-67.0 \%$.

The coefficients of digestion of fat and nitrogen-free extractives in animals of the breed Charolais and Limousine were the highest. The analogues of other breeds, the use of these substances was at the same level.

Animals of all breeds digested cellulose a little bit worse, and its use was the lowest for the limousine breed. The Hereford breed calves digested fiber the best, which is their breed characteristic.

For a more complete assessment of the effectiveness of the use of animals of different breeds in the new habitat conditions, we investigated some economic indicators. When calculating the profitability of breeding young stock, reproduction indicators were taken into account, in particular, the business output of calves (Table 7).

TABLE VII. ECONOMIC EFFICIENCY OF GROWING BREEDING CALVES FOR A PERIOD OF 18 MONTHS OF GROWING

\begin{tabular}{|c|c|c|c|c|c|}
\hline \multirow[b]{2}{*}{ Rate } & \multicolumn{5}{|c|}{ Breed } \\
\hline & $\begin{array}{l}\text { Heref } \\
\text { ord }\end{array}$ & $\begin{array}{l}\text { Char } \\
\text { olais }\end{array}$ & $\begin{array}{c}\text { Limo } \\
\text { usin }\end{array}$ & Salers & $\begin{array}{c}\text { Aubra } \\
c\end{array}$ \\
\hline $\begin{array}{l}\text { Body weight at the end of } \\
\text { the growing period, } \mathrm{kg}\end{array}$ & 432.2 & 487.5 & 437.9 & 451.6 & 457.5 \\
\hline Received gain, $\mathrm{kg}$ & 406.4 & 451.1 & 406.3 & 424.7 & 429.2 \\
\hline $\begin{array}{l}\text { Spent EFU per } 1 \mathrm{~kg} \text { of } \\
\text { growth }\end{array}$ & 6.83 & 6.49 & 6.84 & 6.53 & 6.53 \\
\hline $\begin{array}{l}\text { The cost of obtaining and } \\
\text { growing of } 1 \text { head, rub }\end{array}$ & $\begin{array}{c}25097 \\
.4\end{array}$ & $\begin{array}{c}38308 \\
.6\end{array}$ & $\begin{array}{c}32606 \\
.5\end{array}$ & $\begin{array}{c}29920 \\
.7\end{array}$ & $\begin{array}{c}30410 \\
.6\end{array}$ \\
\hline $\begin{array}{l}\text { The cost of } 1 \text { centner of } \\
\text { growth, rub }\end{array}$ & $\begin{array}{c}6175 . \\
5\end{array}$ & $\begin{array}{c}8492 . \\
2\end{array}$ & $\begin{array}{c}8025 . \\
2\end{array}$ & $\begin{array}{c}7045 . \\
1\end{array}$ & $\begin{array}{c}7085 . \\
4\end{array}$ \\
\hline $\begin{array}{l}\text { Proceeds from the sale of } 1 \\
\text { head, rub }\end{array}$ & $\begin{array}{c}41491 \\
.2\end{array}$ & 46800 & $\begin{array}{c}42038 \\
.4\end{array}$ & $\begin{array}{c}43353 \\
.6\end{array}$ & 43920 \\
\hline Profit on 1 head, rub & $\begin{array}{c}16393 \\
.8 \\
\end{array}$ & $\begin{array}{c}8491 . \\
4\end{array}$ & $\begin{array}{c}9431 . \\
9\end{array}$ & $\begin{array}{c}13432 \\
.9\end{array}$ & $\begin{array}{c}13509 \\
.4\end{array}$ \\
\hline Profitability level, $\%$ & 65.3 & 22.1 & 29 & 45 & 44.4 \\
\hline
\end{tabular}

Payment for feed products for experimental calves had unequal values, which was directly dependent on the growth rate of the young.

Analysis of the economic efficiency of growing young showed that the greatest profit from sales of 1 head was 46,800 rubles for calves of the Charolais breed, but when comparing all costs, the greatest profit was obtained from selling animals of the Hereford, Salers and Aubrac breed: 16393.8; 13432.9 and 13509.4 rubles. respectively.

On the basis of all economic indicators, the profitability level of breeding animals was the highest among the Hereford bulls. Calves of the Salers and Aubrac breed were inferior to Herefords in terms of cultivation efficiency by 20.3 , and $20.9 \%$, limousines by $36.3 \%$, and the maximum Charolais almost doubled (43.2\%).

On the basis of our own research, we also presented the biotechnological characteristics of the used meat breeds of livestock (Table 8).
TABLE VIII. BIOTECHNOLOGICAL CHARACTERISTICS OF MEAT BREEDS OF LIVESTOCK OF THE TYUMEN REGION, SCORE

\begin{tabular}{|l|c|c|c|c|c|}
\hline \multirow{2}{*}{\multicolumn{1}{|c|}{ Rate }} & \multicolumn{5}{|c|}{ Breed } \\
\cline { 2 - 6 } & Hereford & $\begin{array}{c}\text { Charola } \\
\text { is }\end{array}$ & $\begin{array}{c}\text { Limousi } \\
n\end{array}$ & Salers & Aubrac \\
\hline Ease of calving & 4 & 2.5 & 3 & 3.8 & 3.7 \\
\hline Maternal qualities & 4.5 & 3.8 & 4 & 4.5 & 4.5 \\
\hline Milkness & 4.2 & 4.7 & 4.6 & 4.3 & 4.3 \\
\hline $\begin{array}{l}\text { Modesty of } \\
\text { requirements }\end{array}$ & 4.2 & 2.5 & 3.5 & 4 & 4 \\
\hline Cold resistance & 4 & 3 & 3.1 & 3.5 & 3.6 \\
\hline Economic life & 4.5 & 4.5 & 4.5 & 4.5 & 4.5 \\
\hline Calves output & 4.2 & 3 & 3.5 & 4.1 & 4.1 \\
\hline Precocity & 4.2 & 3.2 & 3.75 & 4.0 & 4.1 \\
\hline Marbling oa meat & 4.5 & 3.2 & 3.2 & 3 & 3 \\
\hline Taste of meat & 4.5 & 4 & 4 & 4 & 4 \\
\hline Average score & 4.28 & 3.44 & 3.84 & 3.97 & 3.98 \\
\hline Position & 1 & 5 & 4 & 2 & 2 \\
\hline
\end{tabular}

The highest score -5 points, the lowest -1 point

The success of breeding beef cattle is determined by a set of economically useful qualities, which include reproductive qualities, growth intensity, meat quality, technological features of the breed, and other indicators. And in the end, the leading value of the integrated technological indicators for the conditions of the Northern Trans-Urals differed animal breeds Hereford, then the "extensive" breeds Salers and Aubrac and closes the rating of such "cultural" breeds as Limousine and Charolais.

The results obtained over a fifteen-year period of breeding specialized beef cattle in the Tyumen region show an increase in the main productive indicators of animals of all introduced breeds. The annual increase in livestock amounts to $10-12 \%$, the age of insemination of heifers is reduced to 19 months, the business output of calves reaches $87 \%$, the milk content of calves is $237 \mathrm{~kg}$ and in calves up to $218 \mathrm{~kg}$. In general, the assessment of the complex of productive qualities shows that more than $90 \%$ of animals fully comply with the requirements of the standard. All this directly indicates a good acclimatization of imported beef cattle and the success of the development of beef cattle in the Tyumen region.

\section{References}

[1] H. A. Amerkhanov, I. V. Shchukina, F. G. Kayumov, B. G. Rogachev, "Productivity of cows of meat breed Charolais", Husbandry, 2015, No. 8, pp. 23-25.

[2] A. S. Donchenko, V. K. Kalichkin, R. P. Minakov et al, "Interregional scheme of placement and specialization of agricultural production in the subjects of the Russian Federation in the Siberian Federal district", Novosibirsk, 2016.

[3] A. S. Durov, V. S. Deeva, "Economic and biological characteristics of the genealogical lines of Hereford cattle Siberian breeding", Bulletin of Altai state agricultural university, 2014, vol. 10 (120), pp. 90-95.

[4] N. G. Gamarnik, V. A. Soloshenko, O. M. Sheveleva, V. N. Tulupov, V. N. Vasiliev, P. T. Zolotarev, Beef cattle the Northern Urals: state of art and prospects for development. Novosibirsk, 2004, p. 248 
[5] B.Zh. Bugasov, N. I. Tatarkina, "Some questions of adaptation of imported cattle in the North of Kazakhstan", Bulletin of State agrarian University of Northern Zauralye, 2016, vol. 3 (34), pp. 35-39.

[6] V. A. Soloshenko, V. G. Guglya, P. T. Zolotarev, N. G. Gamarnik, I. A Khramtsova, "Specialized beef cattle of Siberia, problems and their solution", Chief livestock, 2013, No. 3, pp. 20-32.

[7] V.Ya. Kavardakov, I.A. Semenenko, S.V. Sazonov, "The Technological development of cattle breeding in Russia: The Modern condinion, problems and their solutions", Problems of the agricultural market, 2013, no. 3, pp. 78-80.

[8] D.I. Eremin, D.V. Eremina, "Influence of transport infrastructure on water permeability of soil of Western Sibiria”, IOP Conference Series: Earth and Environmental Science, vol. 90, 2017. doi.org/10.1088/17551315/90/1/012111

[9] N. M. Rostovtsev, O. N. Kashirina, O. V. Ivanova, "Acclimatization and adaptation of Aberdeen Angus cattle in the Krasnodar region", Collection of scientific works of all-Russian scientific research Institute of sheep breeding and goat breeding, 2014, Vol. 3, No. 7, pp. 250-253.

[10] V. V. Stanchinsky, "Theoretical basis for the acclimatisation of animals", Comp. scientific. Proc. of Institute of agricultural hybridization and acclimatization of animals in Askania Nova, Moscow-Leningrad, 1933, chapter 1, pp. 33-66.

[11] L. P. Prakhov, G. A. Chernov, Guidelines for the study of acclimatization abilities of cattle of meat breeds. Orenburg. 1977, p. 24

[12] A. I. Ovsyannikov, Fundamentals of experimental work in animal husbandry. Moscow: Kolos, 1976, p. 304

[13] D.T.Degefie, E. Fleischer, O. Klemm, A.V. Soromotin, O.V Soromotina, A.V. Tolstikov, N.V. Abramov, "Climate extremes in South Western Siberia: past and future", Stochastic Environmental Research and Risk Assessment, vol. 28 (8), pp. 2161-2173.

[14] M.A. Chasovshchikova, O.M. Sheveleva, M.A. Svjazhenina, N.I. Tatarkina, A.B. Satkeeva, A.A. Bakharev, E.A. Ponomareva, A.G. Koshchaev, "Relationship between the genetic variants of kappa-casein and prolactin and the productive-biological characteristics of cows of the black-motley breed", Journal of Pharmaceutical Sciences and Research, vol. 9, no. 7, July 2017, pp. 1038-1044.

[15] A.V. Garkovenko, V. V. Radchenko, E. V. Ilnitskaya, A. G. Koshchaev, I. V. Shchukina, A. A. Bakharev, S. F. Sukhanova, "Polymorphism of cattle microsatellite complexes" Journal of Pharmaceutical Sciences and Research, Vol. 10(6), 2018, pp. 1545-1551. 